\section{JIBM}

Journal of International Business and Management (JIBM) Journal Homepage: https://rpajournals.com/jibm

\title{
Strategic Alliances and Performance of Firms in the Motor Vehicle Industry in Nairobi County
}

\author{
Job Wafula Khisa" \\ Paul Kariuki ${ }^{2}$ \\ Jomo Kenyatta University of Agriculture and Technology, Kenya'
}

\begin{abstract}
The current study sought to establish the effects of strategic alliances on performance of firms in the motor vehicle industry in Nairobi County, Kenya. The study specifically focused on assessing how technological alliances, marketing alliances, production alliances and logistics alliances affect performance of firms in motor vehicle industry in Nairobi County. The study was anchored on Resource Dependency Theory, Transaction Cost Theory, Knowledge Management Theory and Organizational Learning Theory. The study adopted a descriptive research design and targeted 18 firms in the automobile industry and operating in Nairobi County. The unit of observation comprised of 315 employees from the selected motor vehicle firms and occupying managerial positions. The study employed Slovenes Sampling formula in deriving a sample size of 158 respondents. Primary data was collected through a 5-point Likert scale questionnaire and analysed through both inferential and descriptive statistics. The statistics were generated by the help of SPSS and Ms Excel. The results of the analysis were presented using tables. The study established that producttion alliances and logistics alliances positively and significantly affect performances of motor vehicle industry (Beta $=0.410$, sig $=0.000<0.05$ and beta 0.301 , sig $=0.001<0.05$ ). The study further established that technological alliances and marketing alliances positively but insignificantly affect performance of motor vehicle industry ( $($ Beta $=0.128$, sig $=0.089>0.05$ and beta 0.109 , $\operatorname{sig}=0.126>0.05)$. The results imply that enhancing increasing each of the variables with their one unit results to performance increase of the motor vehicle industry with the respective beta values. The study recommended that for there to be an enhanced performance amongst motor vehicle industry players in Nairobi County, there is a need for the firms to engage in alliances that contributed to operational effectiveness in areas of technology, marketing, production and logistics.
\end{abstract}

Keywords: Technological Alliances, Marketing Alliances, Production Alliances, Logistics Alliances and Performance of Motor Vehicle Firms

*Corresponding author: Job Wafula Khisa; Email: wafula.wafulak.khisa@gmail.com DOI: https://doi.org/10.37227/JIBM-2022-02-5310

\section{Background of the Study}

The automotive industry is considered one of the most important sectors that contribute to a country's economy. Currently, the use of the passenger cars specifically within developed countries calls for an increase in the number of imported as well as exported cars (Law, Daud, Hamid \& Haron, 2017). The overall performance of motor vehicle companies within the industry depends on the level of 
competitiveness and cooperation that serves as a definite business strategy. Such a strategy allows the participating firms to perform better in terms of market share, profitability, technical improvements depending on particular interests and objectives. Notably, the formation of strategic alliances serves different purposes such as spreading of risk, increase in the percentage of market share, preempting resources, accessibility to new markets alongside gaining organizational aspect of learning. The technological industry regards different functions such as knowledge acquisition and transfer alongside generation of technology as the foundational motives of strategic alliances within such industries (Law et al., 2017). Such an aspect correlates to the idea that strategic alliances may influence to an extent the level of performance of automotive firms as per the resource-based theory.

According to Bamel et al. (2021) strategic alliances are formed when two or more firms join to achieve certain goals that they agree upon. Klus et al, (2019) further point out those firms entering strategic alliances share resources to achieve superior organizational performance and increase their reputation and market share since they have access to a pool of resources and competencies that they didn't have as individuals. Cui et al, (2018) further indicate that firms in strategic alliances pool properties, resources, competencies and expertise to realize mutual objectives. This is informed by the fact that the information, properties, resources, competencies, and expertise needed to enhance the profitability of the individual firms exist outside the firms themselves. The firm's management lacks direct control of these key resources. Through strategic alliances, firms are provided with opportunities to benefit from new information, expertise and develop new competencies.

The alliances are wide-ranging associations including franchises, joint research and development, long-term supply arrangements, outsourcing, joint ventures and joint marketing. Successful alliances become firms engine for growth and profitability globally and/or in the local market. Strategic coalitions offer a chance for companies to partner in business operations which is very helpful in reducing individual firm weaknesses (Smith and Smith, 2003). According to Bernadette (2007), outsourcing as a form of alliance enables firms to lower operational costs, increase customer satisfaction, and enhance firm profitability and productivity.

\section{Statement of the Problem}

Motor sector has continued to report deteriorating performances over the last decade occasioned by stiff competition, changes in operational environment, changes in the demands of customers as well as dynamic customers preferences. The poor performances have seen the sector contribute minimally to the country's economic growth. According to Kenya Automotive Association (2020), the productivity levels of the auto industry has shown a decline in annual sales. In the financial year $2018 / 2019$, the sector was operating at low capacity of $16 \%$ and recorded an annual sale of $\$ 600$. Additionally, the sector accounts for 6\% of GDP contribution which recorded a deficit of $\$ 1.1$ billion thus raising concerns in the sector. The poor performance is attributable to unfair competition which has necessitated the firms to seek strategic alliances. According to Wandia \& Ismail (2019) various organizations depend on strategic alliances for survival. Remarkably, the industry market leaders are identified with active involvement in strategic alliances for the purposes of keeping their strength.

However, there is no research that has been conducted towards analyzing whether market followers within the industry stand the chance of being beneficiaries or risking the selfish practice endeavors. To remain profitable and for optimal performance, motor vehicle companies in Kenya have embraced formation of strategic alliances with companies in other sectors of the economy. The choice of strategic alliances by motor firms in Kenya determines their survival, and performance. According to the Government of Kenya economic survey (2019) the aspect of implementing structural adjustment programs and subsequent market liberalization opened the manufacturing and production sector. This left the businesses at the mercy of market forces. As a result, motor vehicle firms face increased competition and declined profits and even losses. The motor vehicle firms in Kenya have deployed a number of strategic alliances over time including Joint ventures, franchises, joint research and development and joint marketing ventures among others. It is expected that these strategic alliances lead to a firm's improved performance both financially or non-financially. However, it is questionable on how strategic alliances affect the performance of car dealerships and 
body builder firms in Kenya given the large variations in profitability and market share. It would therefore be very useful to establish the effects of strategic alliances on performance of motor vehicle companies.

In this case, several local studies exist on strategic alliances in Kenya. Kasongo \& Misango (2019) details the role of strategic alliances especially on the level of competitiveness concerning Manufacturing industry. The study established that strategic alliances are very useful in enabling firms retain and enhance their competitiveness. The competitiveness of the firms resulting from the alliance is generated through the synergistic effects of the collaboration, a wider customer base, spreading of risk and employment of better technology which consequently reduces the operational cost. However, the research represented a case study, and the current research study represented a survey. Mutuva (2014) investigated the effects of strategic alliance on competitive advantage in Airtel Kenya limited. The study was not generalizable to the ICT sector as it was a case study. The current study, however, was a survey, hence the findings are generalizable.

Agare (2012) focused on factors influencing the success of non-governmental organizations' strategic alliances in Marsabit County, Kenya. The findings indicated that financial capacity of partners, technical capacity of partners, planning and implementation of plans and senior management commitment greatly influence the success of strategic alliance of NGOs operating in Marsabit County. The study only employed descriptive statistics as the method of analysis. The current study, however, employed both descriptive statistics and inferential statistics as the method of analysis. Macharia (2018) focused on the strategic alliances and organizational competitiveness among commercial banks in Kenya. From the study, it was evident that strategic alliances enhance a firm's competitiveness and enable partners to tap into resources, information, capabilities and skills of their partners to gain competitiveness. There is need to establish whether strategic alliances contribute to improved performance of motor companies in Kenya. The study investigated the research question on the effect of strategic alliances on performance of car dealerships and body builder companies in Kenya.

\section{Objectives of the Study}

i. To establish the effect of technological alliances on performance of automobile firms in Kenya

ii. To examine the effect of sales and marketing alliances on performance of automobile firms in Kenya

iii. To assess the effect of production alliances on performance of automobile firms in Kenya

iv. To find out the effect of logistics alliances on performance of automobile firms in Kenya

\section{Theoretical Review}

\section{Literature Review}

\section{Resource Dependency Theory (RDT)}

The RDT of the firm was founded by Wernerfelt in 1984. In line with Resource Dependence Theory (RDT), reliance refers to a phenomenon that "happens when one artist does not entirely manage conditions required to achieve an action or to obtain an outcome as required by the action" (Biermann and Harsch, 2017). The RDT associates create an interorganizational friendship with associates as a law mechanism to deduct uncertainty and manage dependence. Hence, we reason that vertical asymmetric associations and erect symmetric associations can aid the corporation get positive stable anomalous revenues for three reasons; first, commercial partners are self-assured of guidance and commendations recommended by reliable relations, such organizational relations with flexible upstream partners can shorten transaction actions and lessen doubt and deal costs. Secondly, the current uncertainty within the dynamic markets ensures that sharing of information with the upstream and downstream companies becomes more necessary and crucial in sharing information aid the associates updated per the swift market and scientific changes. Thus, 
firms remain capable of quickly adjusting invention strategy. Thirdly, once the associates heed to its suppliers and consumers to the connection problem-solving alliance, their esteem to associates is good to clients and well-received, this helps the associates to maintain proper and stable relationship partners (Biermann and Harsch, 2017).

Apart from the concept of resource exchange or integration, the aspect of resource alignment within the alliance is very crucial. The categorization of resources can take the form of being either supplementary or complementary depending on the exchanged or integrated resources. In this case, the supplementary resources refer to the nature of resources that are easily accessible to the alliance partners prior to the alliance. There are high possibilities that such resources enable firms to consolidate their strengths towards achieving economies of scale alongside risk sharing (Russo and Cesarani, 2017). On the other hand, complementary resources provide larger firms with the ability to leverage their own depth of resources and at the same time, provide smaller firms with the compensation abilities for their lack of resources. Such aspects help in elimination of pre-existing deficiencies (Hora, W., Gast, Kailer, Rey-Marti, \& Mas-Tur, 2018). In this case, the competitive advantage of a company results from the strategy capable of utilizing unique resources as well as skills. The application of resource dependence theory helps deepen the understanding of the nature of resources that are under the control of parent firms. This can be used in explaining the technological alliances. The RDT theory is applicable in this study for the purposes of explaining various effects of a synergy of partner firms on the performance of motor vehicle firms in Kenya.

\section{Transaction Cost Theory}

The Transaction Cost Theory was founded by Williamson in 1986 and asserts that a firm's decision towards transaction mode is possibly subjected under the influence of minimization of the total sum of production alongside transaction costs (Schmidt \& Wagner, 2019). This theory works well with the marketing alliances. In this scenario, the various players within the industry presumably fall for the option within the spectrum of 'market and hierarchy' that provides for cost minimization (Williamson, 2010). In this case, the term hierarchy refers to internalization of functions of players in the form of firms contrary to using the market (Schmidt \& Wagner, 2019). Despite the markets and hierarchies representing polar opposites, alliances are possibly identified as falling in between the spectrum. The better understanding of transaction cost theory as regards formation of alliances, there is possible essentiality in understanding the occurrence of transaction costs within environments that could possibly act in favor of alliance formation. The existence of narrow markets where firms are considered to heavily rely on individual suppliers for specialized products, there is the inclination of players towards high commitment owing to high switching costs. Schmidt \& Wagner (2019) refer to concept as asset specificity, meaning that assets can be highly specific for a transaction, leading to higher transaction costs. However, firms are required to closely monitor and rely on each other, therefore, forcing the aspect of contract signing for protection against acts of deception alongside opportunism. There is however some level of impossibility when it comes to prediction of every change within the environment, which ensures that contracts always were incomplete. The existence of uncertainty over each other's performance provides some form of fundamentality in the choice of alliance formation. However, the aspect of shared internalization could also be a viable alternative if transaction costs are of an intermediate level that do not justify own internalization (Schmidt \& Wagner, 2019). 


\section{The Knowledge-Based View (KBV)}

The knowledge-based view provides one of the alternative perspectives on the organization together with the competitive advantages of the organization. The KBV was extended by Conner (1991) as an extension of RBV which was first suggested by Penrose in 1959 and then further explored by Wernerfelt and Rumelt in 1984. This theory considers all productivity as knowledge dependent, meaning that the competitive advantages of an organization are based on the creation as well as integration of knowledge (Mejri, MacVaugh \& Tsagdis, 2018). Knowledge is divided into two separate parts, which are knowledge itself and tacit knowledge. The two categories can be differentiated by use of transferability of knowledge. In this case, tacit knowledge is identified by its application as well as its acquisition through practice.

In relation to the motor vehicle industry, there are different knowledge-based factors that influence forming of strategic alliances. For instance, firms may lack the means of producing enough technology alongside knowledge that could enable them to compete on their own. The various processes such as rapid technological change, short product cycles, high costs as well as risks in development and time for knowledge production calls for an organization to seek external knowledge (Cuypers et al., 2021). The aspect on efficient use of knowledge calls for coordination of different kinds of specialized knowledge, not always possible through the market. Despite the market being unviable, the issue remains that it is not easy the full utilization of knowledge alone. In such a case, alliance formation is a preferred alternative owing to the efficiency of transfer means as well as integration of knowledge as compared to the market. This concept best fits the explanation of production alliances. However, one of the disadvantages is that in the event of alliance termination the dependent partner is left stranded.

\section{Organizational Learning Theory (OLT)}

This theory on organizational learning does not simply refer to the sum of each member's learning (Cuypers et al., 2021). The idea of OLT was developed by Chris Argyris and Donald Schon in 1996. Despite the fact that all learning occurs inside the human brain, there is the aspect of being distracted by the social influences. Further, the nature of knowledge generated by the individuals does not always benefit an organization independently of other individuals. This theory serves as an intrinsically social and collective phenomenon, with the results deeply being linked to the conditions under which it takes place. Notably, organizations, apart from individuals, develop and maintain learning systems that have broad influence being transmitted to others through organizational histories and norms.

Importantly, knowledge provides a good basis for organizations to build understanding of their environment, therefore, resulting in informed alliances and associations. In this study, the implication of the collective view of learning denotes that, organizational learning focuses on changes in organizational practices, however, organizational practices do not always relate to individual knowledge. In the case of strategic alliances in the motor vehicle industry, the organizational learning is not purely cognitive but considered as a process of social adaptation, learning as well as modifying organizational rules, and development of shared interaction patterns. The organizational learning, basically characterized by path dependencies, works best with production alliances where initial practices as well as routines help in shaping as well as constraining the future activities and learning (Russo and Cesarani, 2017). 


\section{Conceptual Framework}

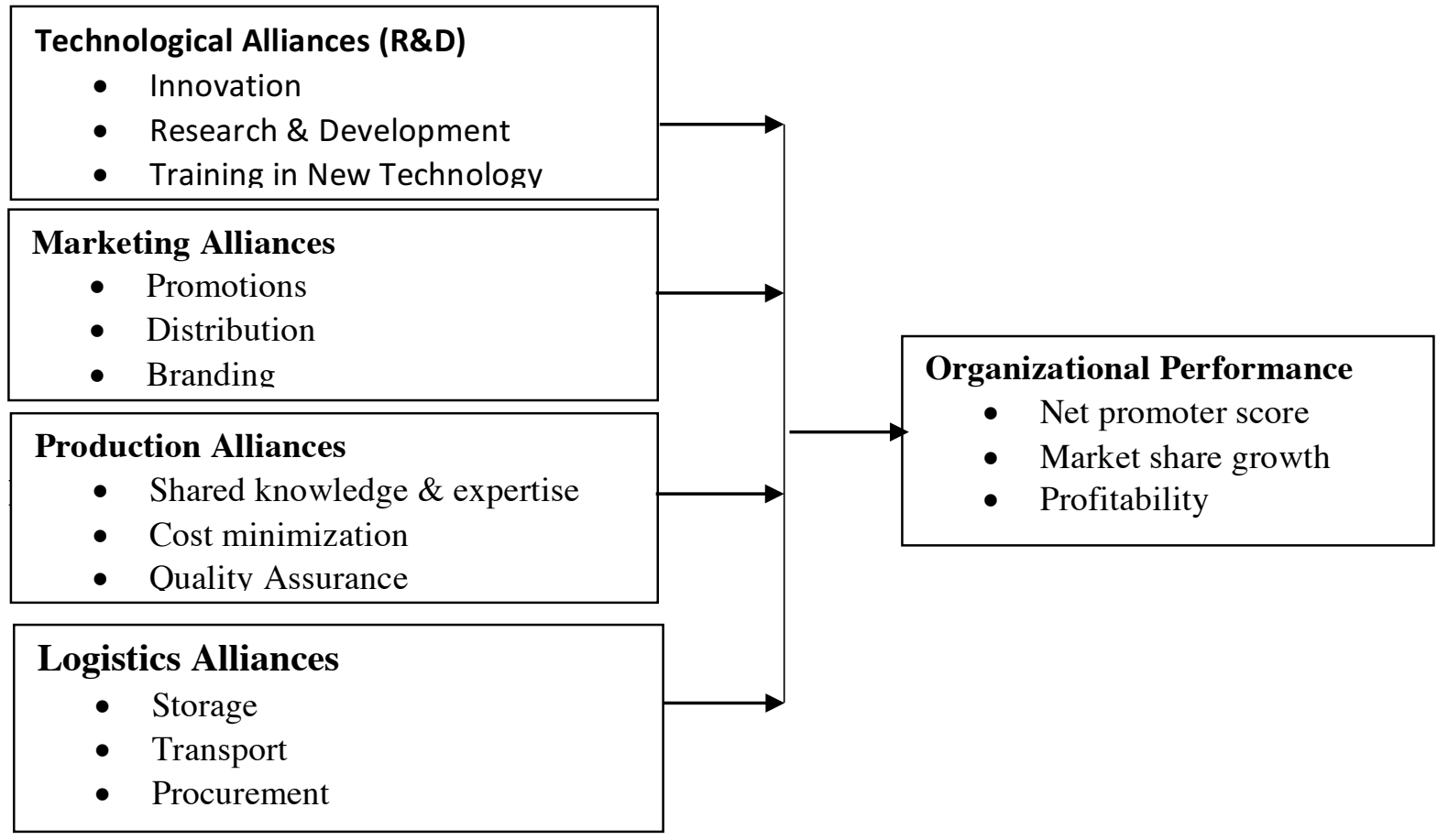

\section{Figure 1: Conceptual Framework}

Technological/Research and Development (R\&D) Alliances

Rapid technological developments within technology companies, skyrocketing costs, staying abreast amidst various market challenges etc., prompts and increases functional associates that emphasizes the application of Research \& Development. On technological alliances, the associates decide to take cooperative research and innovate new products and services. Example is the typical Research \& Development alliance formed in the year 2000 amongst Intel, Micron Technology, Hyundai, Samsung, Siemens and NEC that focused on ensuring creation of the new next generation of DRAM chips. Likewise, Bayer A\&G formed Research \& Development alliances using the smaller biotechnology corporations like Morphosys alongside Millennium Pharmaceutical for strengthening their joint research findings. The research and development $(R \& D)$ alliances entail an agreement where the partners reach an agreement of undertaking a joint research towards the development of new products and services. This occurs to make-up for the short technology life cycles alongside rising costs in research and development (R\&D).

In most instances, the R\&D alliances take the form of cross-licensing rather than joint ventures. The organizations come together to research and develop new products or processes to satisfy world markets (Darby et al., 2020). Alliance International (2020) indicates that various firms within different industries such as Volkswagen, Microsoft, Google as well as Amazon combined spent approximately $\$ 35$ billion on Research and Development (R\&D) as per 2015 records. The statistics as per Alliance International indicate that the most recognizable Multinational companies have spent greatly on their R\&D. Such level of spending begs the question on why the companies spend billions only on R\&D as compared to other activities. The reason is that researching, and application of the knowledge gained from research for the development of new as well as different products, properties, 
policies and processes helps in the creation of more profitable business opportunities. Research \& Development in the automobile industry provides new ideas as well as innovation where applicable (Yuan et al, 2019). Currently, the many products used within the global market results from investments in research and development.

\section{Marketing Alliances}

A Marketing alliance refers to a functional alliance whereby various associates share many marketing expertise and services. In most instances, the partner brings forth their goods and services to the market in the presence of other parties. The established firm helps the newcomer through promotions, advertisement, and/or distributing its products or services. In this case, the nature of arrangement involves one partner introducing their products or services into a defined market where the other partner already has a presence. In this case, the established partner provides the newcomer with the necessary assistance in exchange for a fee (Bamel et al., 2021). Most firms require the implementation of appropriate marketing strategies for the purposes of forming synergistic strategic alliances. Such a strategy helps the firm maintain their competitiveness within their market space. According to Porter (1985 as cited in Kharub, Mor \& Sharma, 2019), there exists three competitive marketing strategies that include: overall cost leadership, differentiation and focus strategies.

In overall cost leadership strategy, firms compete within their market spaces through becoming cost leaders especially by promotion of their product or service as the one providing best value. The success with such a strategy does not necessarily require the firm to provide the lowest price despite being an advantage at particular market spaces. Different firms have adopted the concept of value pricing whereby they charge fairly low price to loyal customers for high-quality products. The meaning derived from the approach is that value pricing is a matter of reengineering the operations of the firm towards becoming a low-cost producer without compromise on quality. Such an approach attracts a large number of value-conscious customers (Kotler \& Keller, 2016). The application of differentiation strategy focuses on the fact that a firm can compete within its market domain as the only unique producer of a specific product or service within the specific industry. Research reveals that in most instances brand image as well as uniqueness is considered more compelling as compared to pricing. The idea of identifying oneself with uniqueness creates and makes one feel special (Kotler \& Keller, 2016). Focus strategy demands that the firm's competitiveness should be defined by a very narrow segment of their industry that focuses on performing a particular activity above the rest in the industry. For instance, the firm decides in perfecting on one activity better than the rest within a specific segment of the target industry. In this case, the firm's creative energies are directed into a particular thing.

\section{Production Alliances}

This relates to the functional alignment when two or more associates all produce products or provide all services within a shared and joint facility. Production associates may manage a facility that a partner already got. Examples, NUMMI joint venture with GM and Toyota housed former GM congress plant in US California, before the association closed. Alternatively, partners can choose to make another plan, for instance the brand new approximately $\$ 3$ billion combined venture between Sharp and Sony for production of crystal liquid panels for definition television in Japan (Cacciolatti et al., 2020). In production alliances two or more firms each take the responsibility of manufacturing products or provision of services within a shared or rather a common facility. Such alliances occur severally within the auto as well as computer industries. For instance, in the alliance between Nissan and Renault, the consolidated data of the alliance on the aspect of manufacturing designates Nissan as the key actor of the growth in production. The growth in production volume was attributed to the recovery of Nissan's operations within the United States of 
America's market. The main achievements from Renault's perspective in the comanufacturing process include cross-production of various car components such as engines, increase in capacity to manufacture Renault's models as well as improvement in co-assembly of light commercial vehicles sold to the Argentina market (Chanaron \& Jullien, 2018).

\section{Logistics Alliances}

A logistic alliance according to Delfmann and Thonemann (2015) refers to a team or a group of trading specialists who work together with the aim of helping firms to successfully and competently deliver and manage their products. Joto (2018) adds that logistics alliances can be viewed as formalized cooperative and long-term relationships between at least one LSP(Logistic Service Provider) and another legally independent actors within the supply chain with the aim of striving for mutual competitive advantage. Firms bears the abilities of joining or hiring logistic alliances groups with the aim of empowering the alliance group to establish supply chains, assistances as well in offering firms with advisory services to place them at better performance and competitive level. Emami et al., (2022) notes that the demands for logistic alliance is necessitated by the firms needs of transporting produces services or products to long distance buyers and consumers. Firms opt for logistic alliances since they find difficulties in acquiring resources, vehicles and in performing management activities necessary for establishing an effective supply chain while at the same time managing costs.

Therefore, such firms engage logistic providers and form logistic alliances which helps the firms in complementing business functions through simplifying supply chain operations. Strategic logistic alliances serve as means through which the parties involved in the alliance improves their brand awareness and capital without necessarily spending more time or incurring a major financial expenditure (Emami et al., 2022). Joto (2018) highlights that firms engaged in logistic alliances gain from reduced risks and costs since there is distribution across the involved parties in the alliance. A firm can benefit from higher economies of scale in the alliance since there is a high possibility of increasing volume of production occasioned by a reduction in per unit cost. Additionally, the parties involved in the alliances can jointly utilize their specialization in creating additional value beneficial to the market. Delfmann and Thonemann (2015) adds that in addition to offering supply services to firms, logistic alliances assist firms in managing their inventories in areas of inventory optimization, planning optimization and warehouse optimization. Consequently, the logistic alliances provide firms with business strategic planning practices that lay a role in designing, developing as well as implementing policies associated with product management.

\section{Organizational Performance}

An organization's enactment on the associates' aptitude as well as adventure resources shows how good such an initiative could help the firm achieve its goals (Salvato \& Rerup, 2018). According to Berberoglu (2018), the firms' competencies and accomplishment of the set goals are assessed to measure firm performance. Firm enactment meets set managerial objectives and goals for a given period which is equivalent to efficiency, effectiveness and economy, quality, consistent conduct and required measures. Calculating associate enactment can too be achievable through stable scorecard that measures associate's learning to growing, internal trade processes, financial enactment to customer enactment. The threeway bottom track performance extent also emphasizes on communal economic, ecofriendly and social enactment (Salvato \& Rerup, 2018). Enactment is function to several issues key 
amid them competitive plans, then this also can be influenced through information structure and same to supply chain organization practices.

Cacciolatti et al. (2020) suggest that strategic alliances are crucial in helping companies to attain the evolving client requirements, as well as achievement of high firm performance and still command a substantive market share within the regulated markets. The formation of strategic alliances proves to be one of the most useful strategies capable of enabling companies' aspect of retention alongside increasing the market share within highly dynamic as well as competitive global markets. This also includes maintaining high levels of profitability over long periods. However, the implementation of the alliances should align to the overall corporate strategy of the respective partners. Salvato \& Rerup (2018) established that companies in alliances freely utilize their partners' various strengths such as competencies, expertise, as well as strategic resources. Notably, large corporations currently join alliances with medium-sized firms within the same industries for the purposes of improving their reputation, competitiveness, as well as level of performance that reduces risks and costs.

\section{Research Methodology}

The study adopted a descriptive research design. The target population comprised of 18 targeted automobile firms operating in Nairobi County as captured in the Register of Industries (2019). The unit of observation comprised of 315 employees from the selected motor vehicle companies. The study employed Slovenes Sampling formula to derive a sample of 158 respondents drawn from top, middle and lower managerial positions. Primary data was collected through a semi-structured questionnaire containing both open-ended and closed-ended questions. Descriptive and inferential statistics generated through SPSS and MS Excel were used to analyse the data. The study used the following regression model:

$\mathbf{Y}=\boldsymbol{\beta}_{0}+\boldsymbol{\beta}_{1} \mathbf{X}_{1}+\boldsymbol{\beta}_{2} \mathbf{X}_{2}+\boldsymbol{\beta}_{3} \mathbf{X}_{3}+\boldsymbol{\beta}_{4} \mathbf{X}_{4}+\boldsymbol{\varepsilon}$

$Y=$ Performance of Firms, $\alpha=$ Constant (coefficient of intercept), X1 =

Technological/R\&D Alliances, X2 = Marketing Alliances, X3 = Production Alliances,

$\mathrm{X} 4=$ Logistic Alliances, $\mathrm{e}=$ Error term and $\beta 1, \beta 2, \beta 3, \beta 4=$ Regression coefficient for four variables. The results of the analysis were presented in form of tables and figures.

\section{Results and Discussions}

The researcher targeted a sample size of 158 respondents whom questionnaires were administered to through drop and pick method, as well as via email. Out of the 158 participants a total of 150 responded by filling in the questionnaires and returning them. This was equivalent to $94 \%$ response rate which is considered ideal since it is above $70 \%$, which reflects the works of Mugenda and Mugenda (2012), who stipulated that a response rate of more than $70 \%$ is ideal and excellent for analysis.

\section{Descriptive Statistics Results}

The study adopted descriptive statistics aiming at describing the distribution of measures obtained from responses from items contained in each of the variable in the questionnaire. In providing the descriptive statistics, the study employed both means and standard deviations. While developing the statistics, the researcher requested the respondents to rate their levels of agreement relating to items contained in each of the variable in a scale of 1-5 where $1=$ Strongly Disagree, $2=$ Disagree, $3=$ Neutral, $4=$ Agree and 5= Strongly Agree. The researcher then acquired the mean responses for each of the statements and respective 
standard deviations. The conclusions were made based on the average response means and average standard deviations.

\section{Technological Alliances}

The results presented in table 1 shows that respondents agreed with the statements that entering an alliance enhances the level of innovativeness of a motor vehicle company (mean=3.67), and that research and development leads to introduction of new capabilities in motor vehicle alliances that eventually enhances performance (mean $=3.84)$. Additionally, the respondents were in agreement with the statements that transfer/training in new technology as a result of alliances enhances capacity of firms in Automotive Industry(mean=3.98), that alliances in $R \& D$ enhances the level of quality in production(mean=4.02) and that there is talent enhancement as a result of technological alliances $($ mean=3.98). On average, all respondents were in agreement with statements on technology alliances as shown by average response mean of 3.89 and average std.dev of 0.882 .

Table 1: Descriptive Statistics on Technological Alliances

\begin{tabular}{lcc}
\hline Statement & Mean & Std Deviation \\
\hline $\begin{array}{l}\text { Entering an alliance enhances the level of } \\
\text { innovativeness of a motor vehicle company }\end{array}$ & 3.67 & 1.041 \\
$\begin{array}{l}\text { Research and Development leads to introduction of } \\
\text { new capabilities in motor vehicle alliances that }\end{array}$ & 3.84 & 0.919 \\
$\begin{array}{l}\text { eventually enhances performance } \\
\text { Transfer/training in new technology as a result of } \\
\text { alliances enhances capacity of firms in Automotive }\end{array}$ & 3.98 & 0.817 \\
$\begin{array}{l}\text { Industry } \\
\text { Alliances in R\&D enhances the level of quality in } \\
\text { production }\end{array}$ & 4.02 & 0.616 \\
$\begin{array}{l}\text { There is talent enhancement as a result of } \\
\text { technological alliances } \\
\text { Average }\end{array}$ & 3.98 & 1.017 \\
\hline
\end{tabular}

\section{Marketing Alliances}

The results displayed in table 2 shows that respondents agreed with the statements that promotions resulting from strategic alliances improves market operations of Motor vehicle firms $($ mean=3.97), that strategic market alliances result into efficient market distribution system that enhances a firms operations $($ mean $=4.12)$ and that the branding system resulting from marketing alliances increases the ability of a motor vehicle firm to penetrate the market(mean=3.98). Additionally, respondents were in agreement with the statements that strategic market alliances help improve timely delivery, product availability and product returns in the market for a motor vehicle firm (mean=4.09) and that alliances in marketing enhances the capability of the firm of extending market share(mean=3.54). An average response mean of 3.94 and average std.dev of 0.769 shows that all respondents were in agreement with all statements pertaining marketing alliances. 
Table 2: Descriptive Statistics on Marketing Alliances

\begin{tabular}{lcc}
\hline Statement & Mean & Std.Dev \\
\hline $\begin{array}{l}\text { Promotions resulting from strategic alliances improves } \\
\text { market operations of Motor vehicle firms }\end{array}$ & 3.97 & 0.823 \\
$\begin{array}{l}\text { Strategic market alliances result into efficient market } \\
\text { distribution system that enhances a firm's operations }\end{array}$ & 4.12 & 0.482 \\
$\begin{array}{l}\text { The branding system resulting from marketing alliances } \\
\text { increases the ability of a motor vehicle firm to penetrate the } \\
\text { market }\end{array}$ & 3.98 & 0.813 \\
$\begin{array}{l}\text { Strategic market alliances help improve timely delivery, } \\
\text { product availability and product returns in the market for a } \\
\text { motor vehicle firm }\end{array}$ & 4.09 & 0.718 \\
$\begin{array}{l}\text { Alliances in marketing enhances the capability of the firm of } \\
\text { extending market share } \\
\text { Average }\end{array}$ & 3.54 & $\mathbf{1 . 0 0 8}$ \\
\hline
\end{tabular}

\section{Production Alliances}

The results presented in table 4.8 shows that respondents agreed with the statements that shared knowledge and expertise in production alliances improves efficiency in production in firm's processes(mean=4.13), that the aspect of sharing cost of production enhances the performance of motor vehicle firms within the alliances(mean=4.10) and that enhancing the quality assurance capabilities reduces the level of manufacturing defect in motor vehicle firms (mean=3.67). Additionally, the respondents agreed that there is enhanced quality of goods that our firm produces and that cost sharing enables the firm to invest more on other productive areas as shown by average response mean of 4.31 and 3.71 respectively. An average response mean of 3.98 and std.dev of 0.617 shows that all respondents agreed with the statements on production alliances.

Table 3: Descriptive Statistics on Production Alliances

\begin{tabular}{lcc}
\hline Statement & Mean & Std.Dev \\
\hline $\begin{array}{l}\text { Shared knowledge and expertise in production alliances } \\
\text { improves efficiency in production in firm's processes }\end{array}$ & 4.13 & 0.388 \\
$\begin{array}{l}\text { The aspect of sharing cost of production enhances the } \\
\text { performance of motor vehicle firms within the alliances }\end{array}$ & 4.10 & 0.745 \\
$\begin{array}{l}\text { Enhancing the quality assurance capabilities reduces the level } \\
\text { of manufacturing defect in motor vehicle firms }\end{array}$ & 3.67 & 0.814 \\
$\begin{array}{l}\text { There is enhanced quality of goods that our firm produces } \\
\begin{array}{l}\text { Cost sharing enables the firm to invest more on other } \\
\text { productive areas }\end{array}\end{array}$ & 4.31 & 0.328 \\
Average & 3.71 & 0.809 \\
\hline
\end{tabular}

\section{Logistics Alliances}

The results presented in table 4 shows that respondents agreed with the statements that the firm achieves transport objectives from the logistic partners(mean=3.54), that the firm achieves procurement objectives from the logistic partners(mean=3.59), that logistic alliances enable the firm to save on storage and transport expenses(mean=3.61) and that there are enhanced procurement practices in the firm(mean=3.66). Respondents were however neutral on the fact that the firm achieves storage benefits from the logistic 
partners(mean=3.46). On average, however, all respondents were in agreement with statements on logistic alliances as shown by average response mean of 3.57 and std.dev of 1.013 .

Table 4: Descriptive Statistics on Logistics Alliances

\begin{tabular}{lcc}
\hline Statement & Mean & Std.Dev \\
\hline The firm achieves storage benefits from the logistic partners & 3.46 & 1.298 \\
$\begin{array}{l}\text { The firm achieves transport objectives from the logistic } \\
\text { partners }\end{array}$ & 3.54 & 1.016 \\
$\begin{array}{l}\text { The firm achieves procurement objectives from the logistic } \\
\text { partners }\end{array}$ & 3.59 & 0.974 \\
$\begin{array}{l}\text { Logistic alliances enable the firm to save on storage and } \\
\text { transport expenses }\end{array}$ & 3.61 & 0.896 \\
$\begin{array}{l}\text { There is enhanced procurement practices in the firm } \\
\text { Average }\end{array}$ & 3.66 & 0.881 \\
\hline
\end{tabular}

\section{Performance of Automobile Firms}

The results presented in table 5 shows that respondents agreed with the statements that as a result of the automobile firm engaging in strategic alliances, the respective firms have managed to improve the levels of market share (mean= 4.02), profit levels (mean=4.15), firms' operational effectiveness(mean=4.45) as well as reduction in operational $\operatorname{costs}($ mean $=4.42)$.

Table 7: Performance of Automobile Firms

\begin{tabular}{lcc}
\hline Statement & Mean & Std.Dev \\
\hline There has been an improvement in the levels of market share & 4.02 & 0.381 \\
$\begin{array}{l}\text { The profit levels of the firm have increased } \\
\text { Alliances have contributed to the firms' operational }\end{array}$ & 4.15 & 0.319 \\
$\begin{array}{l}\text { effectiveness } \\
\begin{array}{l}\text { Alliances have contributed to the firms' reduction in } \\
\text { operational costs }\end{array}\end{array}$ & 4.45 & 0.208 \\
Average & 4.42 & 0.216 \\
\hline
\end{tabular}

\section{Inferential Statistics Results}

\section{Correlation Results}

The Pearson correlation coefficient $(r=-0.047)$ for the motor vehicle firms' strategic alliances indicated a negative correlation between technological alliances (TA) and performance. Normality test was performed as a preliminary analysis for the purposes of ensuring no violations of the assumptions. The strong negative correlation between the two variables (TA and PF) $r=-0.047, p>0.05$ indicates association between high technological innovations and more manufacturing alongside distribution as opposed to sales to consumers, therefore, resulting in low motor vehicle firm performance. The Pearson Correlation coefficient (-.150) for motor vehicle firms indicates a negative correlation between marketing alliances and firm performance. In this case, the weak negative correlation between the two variables $(\mathrm{r}=-.15, \mathrm{p}<0.05, \mathrm{n}=150)$, indicates that increase in levels of marketing through alliances is associated with high performance of motor vehicle 
firms. The Pearson Correlation coefficient $(0.425)$ for the firms indicates a strong positive correlation between the two variables $\mathrm{r}=0.425, \mathrm{p}<0.05, \mathrm{n}=150$ (production alliances and performance) of the firm. In this case, the high levels of production in alliances result into more manufacturing and distribution, therefore, high firm performance.

The table 4.11 indicates a positive correlation existing between production alliances and firm performance $(\mathrm{p}=0.425)$. This shows no statistically significant relationship between PA and performance of motor vehicle firms since the significant value is less than 0.05 . The interpretation could be that entering product alliance leads to performance improvement within the automobile industry in Kenya. This may be attributable to high chances of the individual firm entering alliance gaining focus of their core functions in the market. The correlation results show that logistics alliances positively and significantly correlate with performance of automobile firms. This is shown by correlation coefficient of .367 and sig value of .002 . The results imply that enhancing logistics alliances practices enhances the performance levels of the automobile firms. This can be attributed to the fact that logistic outsourcing enables a firm to save on costs in areas of transport, storage and procurement.

Table 8: Correlation Analysis

\begin{tabular}{llrrrrr}
\hline \multicolumn{7}{c}{ Correlations } \\
\hline & \multicolumn{1}{c}{ PF } & TA & MA & PDA & LA \\
\hline Pearson & PF & 1.000 & & & & \\
Correlation & TA & -.047 & 1.000 & & & \\
$(\mathrm{r})$ & MA & -.150 & .827 & 1.000 & & \\
& PDA & .425 & .063 & .010 & 1.000 & \\
& LA & .367 & .009 & .102 & .261 & 1.000 \\
\hline Sig. (2- & PF &. & & & & \\
tailed) p- & TA & .285 & & & & \\
values & MA & .034 & .000 & & & \\
& PDA & .000 & .221 & .451 & & \\
& LA & .002 & .176 & .067 & 0.048 & \\
\hline $\mathrm{N}$ & & 150 & 150 & 150 & 150 & 150 \\
\hline
\end{tabular}

\section{Multiple Regression Analysis}

Table 9 shows the degree of relationship between independent variables (technological alliances, marketing alliances, production alliances and logistic alliances) and dependent variable (performance of automobile firms). According to the results, there exists a moderately high relationship between independent and dependent variables as shown by $\mathrm{R}$ value of .647 . The coefficient of determination represented by $\mathrm{R}$ square value of .419 implies that $41.9 \%$ of performance in automobile firms is accounted by technological alliances, marketing alliances, production alliances and logistic alliances.

Table 9: Model Summary

\begin{tabular}{llll}
\hline $\mathbf{R}$ & R Square & Adjusted R Square & Std. Error of the Estimate \\
\hline $.647^{\mathrm{a}}$ & .419 & .381 & 1.371563 \\
\hline
\end{tabular}

a. Predictors: (Constant), TA, MA,PDA and LA

The ANOVA results outlined in table 10 shows that the model linking strategic alliances (technological alliances, marketing alliances, production alliances and logistic alliances) 
and performance of automobile firms in Nairobi County was statistically significant. The conclusion was arrived since the sig value of 0.000 is less than 0.05 level of significance.

Table 10: ANOVA (Model Significance)

\begin{tabular}{llrrrrr}
\hline Model & & Sum of & & & & \\
\hline 1 & Squares & df & Mean Square & \multicolumn{1}{c}{ F } & \multicolumn{1}{c}{ Sig. } \\
\hline & Regression & 47.478 & 4 & 11.8695 & 12.4432 & $.000^{\circ}$ \\
& Residual & 138.314 & 145 & 0.953889 & & \\
\hline
\end{tabular}

a. Dependent Variable: PF

b. Predictors: (Constant), TA, MA, PDA and LA

The results of model coefficient presented in table 11 shows that technological alliances positively but insignificantly affect performances of automobile firms. This is shown by beta value of 0.128 and sig value of $0.089>0.05$. The results imply that increasing technology alliances with one unit increases performances of automobile firms with 0.128 units. The results concur with Jabar et al., (2014) who established that strategic alliances in areas of technology experienced enhanced performances. Specifically, technological alliances in areas of research and development place the firms at a better competitive position. The results further show that marketing alliances positively but insignificantly affects performances of automobile firms. This is shown by beta value of 0.109 and sig value of $0.126>0.05$. The results imply that increasing marketing alliances with one unit increases performances of automobile firms with 0.109 units. The results are consistent with Muange and Kiptoo (2020) findings that joint marketing alliances enhance the performance of firm.

The results also show that production alliances positively and significantly affect performances of automobile firms. This is shown by beta value of 0.410 and sig value of $0.000<0.05$. The results imply that increasing production alliances with one unit increases performances of automobile firms with 0.410 units. The results are in tandem with Wanjiku (2016) who found that production partnership alliances positively and significantly affect performance of firms. The results finally show that logistics alliances positively and significantly affect performances of automobile firms. This is shown by beta value of 0.301 and sig value of $0.001<0.05$. The results imply that increasing logistic alliances with one unit increases performances of automobile firms with 0.301 units. The results tallies with Delfmann and Thonemann (2015) findings which revealed that firms in logistic alliances had positively impacted performance of firms in areas they were conducted.

Table 11: Model Coefficients

\begin{tabular}{llrrrrr}
\hline & & \multicolumn{2}{c}{ Unstandardized } & \multicolumn{2}{c}{$\begin{array}{c}\text { Standardized } \\
\text { Coefficients }\end{array}$} & \multicolumn{2}{c}{ Coefficients } & & \\
\cline { 2 - 5 } Model & \multicolumn{2}{c}{ B } & Std. Error & Beta & \multicolumn{1}{c}{ t } & \multicolumn{1}{c}{ Sig. } \\
\hline 1 & (Constant) & 2.156 & 0.324 & & 6.6543 & 0 \\
& TA & 0.128 & 0.101 & 0.171 & 1.2673 & 0.089 \\
& MA & 0.109 & 0.102 & 0.098 & 1.0686 & 0.126 \\
& PDA & 0.410 & 0.074 & 0.417 & 5.5405 & 0 \\
& LA & 0.301 & 0.213 & 0.281 & 1.4131 & 0.001 \\
\hline
\end{tabular}

The optimal regression model becomes:

Firm Performance $=2.156+0.410($ PDA $)+0.301($ LA $)+0.128($ TA $)+0.109(\mathrm{MA})$ 


\section{Conclusion}

The findings of the study led to conclusion that technological alliances positively but insignificantly affect performance of automobile firms. Additionally, technological alliances practices such as entering alliances that enhances the level of innovativeness, R\&D that leads to introduction of new capabilities, training that enhances capacity of firms in Automotive Industry, enhances the level of quality in production and talent enhancement as a result of technological alliances leads to improved performance levels of automobile firms in Nairobi County. The findings of the study also led to conclusion that marketing alliances positively but insignificantly affects performance of automobile firms. Additionally marketing alliances practices such as promotions that improves market operations, alliances results into efficient market distribution system that enhance a firms operations, branding system resulting to increased market penetration, alliances that help improve timely delivery, product availability and product returns in the market and Alliances that enhance the capability of the firm of extending market share lead to improved performance levels of automobile firms in Nairobi County.

The findings of the study further led to conclusion that production alliances positively and significantly affect performance of automobile firms. Additionally, production alliances practices such as having alliances that contribute to shared knowledge and expertise leading to improved efficiency in production process, alliances that promote sharing cost of production, alliances that enhance the quality assurance capabilities that reduce the level of manufacturing defect, and alliances that enable the firm to invest more on other productive areas lead to improved performance levels of automobile firms in Nairobi County. The findings of the study finally led to conclusion that logistic alliances positively and significantly affect performance of automobile firms. Additionally, logistics alliances that help a firm achieves storage benefits, transport objectives, procurement objectives, having alliances that enables the firm to save on storage and transport expenses and enhances procurement practices leading to improved performance levels of automobile firms in Nairobi County.

\section{Recommendations of the Study}

The study recommended that automobile firms operating in Nairobi County should focus on enhancing their technological alliances since the practice positively improves performance of firms. The firms can achieve this by entering alliances that enhances the level of innovativeness, R\&D that leads to introduction of new capabilities, training that enhances capacity of firms in Automotive Industry, enhances the level of quality in production and talent enhancement as a result of technological alliances. The study further recommended that automobile firms operating in Nairobi County should enhance their marketing alliances since the practice positively improves performance of firms. The firms can achieve greater performance through getting into promotions that improves market operations, alliances result into efficient market distribution system that enhances a firm's operations, branding system resulting to increased market penetration, alliances that help improve timely delivery, product availability and product returns in the market and Alliances that enhance the capability of the firm of extending market share.

The study also recommended that automobile firms operating in Nairobi County should enhance their production alliances since the practice positively and significantly improves performance of firms. This can be achieved through having alliances that contributes to shared knowledge and expertise leading to improved efficiency in production process, alliances that promote sharing cost of production, alliances that enhance the quality assurance capabilities that reduce the level of manufacturing defect, and alliances that enable the firm to invest more on other productive areas. The study finally recommended that automobile firms operating in Nairobi County should enhance their logistics alliances since the practice positively and significantly improves performance of firms. The firms can achieve this by getting into alliances that helps a firm achieves storage benefits, transport objectives, procurement objectives, having alliances that enables the firm to save on storage and transport expenses and enhance procurement practices. 


\section{Limitations and Directions for Future Research}

The management of the motor vehicle firms were hesitant in allowing the researcher to conduct the study in the respective firms. The limitation was addressed by the researcher obtaining an introduction letter from the JKUAT and presenting the same to the management as a sign that the study was purely for academic purposes.

This study explored the impact of strategic alliances on the performance of motor vehicle firms in Kenya. However, similar studies should also be done on other organizations for the purposes of generalizing the findings across companies locally and globally. Additionally, the study established that strategic alliances account for $41.9 \%$ of variables in the performances of automobile firms in Nairobi County. The study therefore recommends another study focusing on other variables not included in the study and which account for $58.1 \%$.

\section{Acknowledgement}

I thank God for His care, wisdom and guidance throughout my academic journey to date; He has surely gone ahead of me. I thank my university supervisor, Dr. Paul Kariuki (PhD) for his patience and guidance throughout my research project writing journey. My gratitude to my classmates for the brainstorming sessions and insights in the making of this research project. Last but not least I wish to most earnestly thank my family for all the support they accorded me throughout my study and my research. May God bless you

\section{References}

Alliance International. (2020). Innovation and Research \& Development. Retrieved from https://alliancecreadvisors.com/rd-related-technology/

Bamel, N., Pereira, V., Bamel, U., \& Cappiello, G. (2021). Knowledge management within a strategic alliances context: past, present and future. Journal of Knowledge Management.

Biermann, R., \& Harsch, M. (2017). Resource dependence theory. In Palgrave handbook of inter-organizational relations in world politics (pp. 135-155). Palgrave Macmillan, London.

Cacciolatti, L., Rosli, A., Ruiz-Alba, J. L., \& Chang, J. (2020). Strategic alliances and firm performance in startups with a social mission. Journal of Business Research, 106, 106-117.

Chanaron, J. J., \& Jullien, B. (2018). The production, distribution, and repair of automobiles: new relationships and new competencies. In Coping with variety (pp. 335-363). Routledge.

Charles, N., Kule, J., \& Kapaya, S. (2021). Effect of Strategic Alliance Management on the Performance of Microfinance Institutions in Rwanda. International Journal of Scientific and Research Publications, 11(5), 176-180.

Cui, V., Yang, H., \& Vertinsky, I. (2018). Attacking your partners: Strategic alliances and competition between partners in product markets. Strategic Management Journal, 39(12), 3116-3139.

Cuypers, I. R., Hennart, J. F., Silverman, B. S., \& Ertug, G. (2021). Transaction cost theory: Past progress, current challenges, and suggestions for the future. Academy of Management Annals, 15(1), 111-150.

Darby, J. L., Ketchen Jr, D. J., Williams, B. D., \& Tokar, T. (2020). The implications of firm-specific policy risk, policy uncertainty, and industry factors for inventory: A 
resource dependence perspective. Journal of Supply Chain Management, 56(4), 324.

Delfmann, W., \& Thonemann, U. (2015). The Management Of Strategic Alliances: Performance Impact Factors and Alliance Management Capabilities in the Context of Logistics Alliances (Ph.D). Universität zu Köln.

Emami, A., Welsh, D., Davari, A., \& Rezazadeh, A. (2022). Examining the relationship between strategic logistic alliances and the performance of small entrepreneurial firms in telecommunications. International Entrepreneurship and Management Journal, 2(4), 78-86.

Hora, W., Gast, J., Kailer, N., Rey-Marti, A., \& Mas-Tur, A. (2018). David and Goliath: causes and effects of coopetition between start-ups and corporates. Review of Managerial Science, 12(2), 411-439.

Jabar, J., Othman, A., \& Idris, A. (2014). Enhancing Organizational Performance Through Strategic Technology Alliances: A Study on Malaysian Manufacturers. International Journal of Innovation, Management and Technology, 2(6), 506--511.

Joto, B. (2018). Effect of Logistics Outsourcing on The Performance Of Dairy Processing Firms In Kenya (Masters). University of Nairobi.Kamau, M. (2020). Strategic Alliance Practices and Organization Performance of Selected Companies In The Energy Sector In Kenya (Masters). Kenyatta University.

Kasongo, P., \& Misango, S. (2019). Effects of Generic Competitive Strategies on organizational performance in the Manufacturing Industry: a case of Bamburi Cement Limited, head office, nairobi. International Journal of Economics, Business and Management Research, 3(2).

Kharub, M., Mor, R. S., \& Sharma, R. (2019). The relationship between cost leadership competitive strategy and firm performance: A mediating role of quality management. Journal of Manufacturing Technology Management.

Klus, M. F., Lohwasser, T. S., Holotiuk, F., \& Moormann, J. (2019). Strategic alliances between banks and fintechs for digital innovation: Motives to collaborate and types of interaction. The Journal of Entrepreneurial Finance, 21(1).

Kotler, P., \& Keller, K. L. (2016). A framework for marketing management. Boston, MA: Pearson.

Law, T. H., Daud, M. S., Hamid, H., \& Haron, N. A. (2017). Development of safety performance index for intercity buses: An exploratory factor analysis approach. Transport policy, 58, 46-52.

Macharia, G. (2018). The Influence of strategic alliances on competitiveness of internationally ranked law firms in Kenya (Doctoral dissertation, Strathmore University).

Mejri, K., MacVaugh, J. A., \& Tsagdis, D. (2018). Knowledge configurations of small and medium-sized knowledge-intensive firms in a developing economy: A knowledgebased view of business-to-business internationalization. Industrial marketing management, $71,160-170$.

Muange, R., \& Kiptoo, N. (2020). Moderating Effect of Firm Size on the Relationship between Joint Marketing Alliances and Firm Performance of Retail Firms in Nairobi County, Kenya. International Journal of Research and Innovation in Social Science, 4(8), 273-284.

Muange, R., \& Maru, L. C. (2015). Strategic alliances on performance of retail firms in Nairobi County, Kenya. The TQM Journal. 
Russo, M., \& Cesarani, M. (2017). Strategic alliance success factors: A literature review on alliance lifecycle. International Journal of Business Administration, 8(3), 1-9.

Ryu, D., Kim, M. H., \& Ryu, D. (2019). The effect of international strategic alliances on firm performance before and after the global financial crisis. Emerging Markets Finance and Trade, 55(15), 3539-3552.

Schmidt, C. G., \& Wagner, S. M. (2019). Blockchain and supply chain relations: A transaction cost theory perspective. Journal of Purchasing and Supply Management, 25(4), 100552.

Setyad, T., Oetom, W., \& Suwitho, K. (2017). The Influence of Strategic Alliance on Competitive Advantage through Market Area and Product Innovation. International Journal of Business Administrat, 8(7), 57-72.

Soatovich, Y. A. (2019). The Conceptual Bases of Multinational and Global Competitiveness Environment and Strategic Alliances. World Science, 3(45), 9-15.

Timmons, J. A., and Spinelli, S. (2007). New venture creation: Entrepreneurship for the 21st century. New York: McGraw-Hill.

Wandia, W. M., \& Ismail, N. O. O. R. (2019). Effects of Strategic Alliances on Performance of Commercial Banks in Kenya: A Case of Kenya Commercial Bank Limited. International Journal of Business Management and Finance, 2(1).

Wanjiku, M. (2016). The Effect of Production Partnership Strategies on Performance of Commercial Banks In Kenya (Masters). University of Nairobi.

William G. Zikmund, Barry J. Babin, Jon C. Carr, Mitch Griffin. (2013). Business Research Methods. CENGAGE Learning Custom Publishing. 